\title{
THE LEGITIMACY OF USING DIETARY SUPPLEMENT DIGLYCOSIDE SECOISOLARICIRESINOL (SDG) FROM FLAXSEED IN CANCER
}

\author{
Karolina Dobrowolskal, Bożena Regulska-Ilow² \\ ${ }^{1}$ Wroclaw Medical University, Doctoral School, Wrocław, Poland \\ ${ }^{2}$ Wroclaw Medical University, Department of Dietetic, Wroclaw, Poland
}

\begin{abstract}
Linseed, commonly known as flaxseed, is a fibre-rich food product. According to the recent study prepared by the American Institute for Cancer Research (AICR), an adequate intake of dietary fiber contributes to reducing the risk of colorectal cancer. In addition, the flaxseed and the oil extracted from it are considered to be food products with a high content of anti-inflammatory, unsaturated $\alpha$-linolenic acid (ALA). However, the authors of the most recent scientific research have assigned the anticancer significance of flax seeds to plant lignan - secoisolariciresinol diglycoside (SDG), of which flaxseed is the main food source. This article provides a review of the world scientific literature together with an assessment of the validity of dietary supplementation with SDG from flaxseeds in cancer and during chemotherapeutic treatment. The paper also presents the European Food Safety Authority (EFSA) and the US Food and Drug Administration (FDA) view on dietary supplementation with flax seeds and its lignans. Additionally, selected dietary supplements available on the Polish market containing SDGs, linseed oil or linseed were analysed, together with a description of their intended use suggested by the manufacturers.
\end{abstract}

Key words: flax seeds, secoisolariciresinol diglycoside, SDG, dietary supplementation, cancer, unconventional treatment

\section{STRESZCZENIE}

Nasiona lnu, powszechnie zwane siemieniem lnianym, należą do produktów spożywczych obfitujących we włókno pokarmowe. Zgodnie z najnowszymi badaniami przygotowanymi przez American Institute for Cancer Research (AICR) odpowiednia podaż błonnika pokarmowego przyczynia się do zmniejszenia ryzyka zachorowania na nowotwór złośliwy jelita grubego. Dodatkowo siemię lniane, oraz powstający z nich olej, zaliczane są do produktów spożywczych zawierających dużą zawartość przeciwzapalnego, nienasyconego kwasu $\alpha$-linolenowego (ALA). Jednak autorzy najnowszych badań naukowych przeciwnowotworowe znaczenie nasion lnu, przypisują lignanowi roślinnemu - diglikozydowi secoisolariciresinolu (SDG), którego głównym źródłem spożywczym jest siemię lniane. W artykule dokonano przeglądu światowego piśmiennictwa naukowego wraz z oceną zasadności stosowania suplementacji diety SDG $\mathrm{z}$ nasion lnu w chorobie nowotworowej oraz $\mathrm{w}$ trakcie leczenia chemioterapeutycznego. W pracy przedstawiono również stanowisko Europejskiego Urzędu ds. Bezpieczeństwa Żywności (EFSA) oraz amerykańskiej Agencji Żywności i Leków (FDA) dotyczące suplementacji diety nasionami lnu oraz jego lignanami. Dodatkowo przeanalizowano wybrane, dostępne na polskim rynku suplementy diety, zawierające w swoim składzie SDG, olej lniany lub nasiona lnu wraz z opisem ich przeznaczenia sugerowanych przez producentów.

Słowa kluczowe: nasiona lnu, diglikozyd secoisolariciresinolu, SDG, suplementacja diety, choroby nowotworowe, leczenie niekonwencjonalne

\section{INTRODUCTION}

Nowadays, dietary supplements are a products desirable by consumers. The reason is the dominance of their advertisements in the media and their wide availability, both in pharmacies and markets. Dietary supplements, to some extent, are classified as food in a very specific form, analogous to pharmaceuticals.
This involves some misunderstanding of their function and role in the patient's body. International researches have shown that the society considers dietary supplements as medicines and uses them to treat illnesses or body dysfunctions $[6,51,53,59]$. The increasing popularity of these products may be related to several factors, such as: increased public awareness of the association between nutrition and 
health, increased diagnosis of diet-related diseases, and difficult access to doctors [59].

It is estimated that $50-73 \%$ of patients, diagnosed with oncological disease, decide to use unconventional methods to support their organism in the cancer treatment. Patients often use dietary supplements and other non-conventional preparations that they recommend among themselves [27, 50, 59]. Even about $75 \%$ of doctors do not know about the additional substances used by patients on their own $[27,59]$.

\section{COMMON FLAX (LINUM USITATISSIMUM L.)}

Common flax (Linum usitatissimum L.) belongs to the plants widely grown in the 60's, 70's and 80 's in Poland. At that time, it was grown for fibre, but nowadays, it is increasing in importance as a raw material for seeds and oil. Common flax is characterized by a rare content of unsaturated fatty acids, in which $\alpha$-linolenic acid (ALA) prevails. Flax seeds (or linseeds) are a valuable therapeutic raw material, they are characterized by the content of ingredients with anticancer and antithrombotic effects. Linseed has bioactive components: essential unsaturated fatty acids, mainly ALA, antioxidants, microelements (mainly selenium), lignans [54] and fiber [9]. In cancer diseases, flaxseed is used for both preventive and therapeutic purposes [16].

\section{SECOISOLARICIRESINOL DIGLYCOSIDE (SDG)}

Secoisolariciresinol diglycoside (SDG) belongs to polyphenolic plant lignans, which after oral use is hydrolysed to ecoisolariciresinol (SECO). In the gastrointestinal tract it is metabolized by intestinal bacteria to lignans, biologically active in mammals - enterodiol (END) and enterolactone (ENL) [24]. In an estrogenic environment, lignans act as partial antagonists of this hormone in a tissue-specific manner [10, 24, 39]. The highest SDG concentration is found in linseed, but it is also found in other oilseeds, nuts, full-fat products, pulses, as well as in some vegetables and fruits $[24,56]$. These days, the most common dietary pattern (the so-called western diet) provides $<10 \mathrm{mg} /$ day of lignans $[7,15,24,56]$.

\section{IMPORTANCE OF SDG IN CANCER}

The authors of available preclinical studies emphasize clear therapeutic benefits of a lignan-rich diet with demonstrated reduction of early stages of cancer, as well as inhibition of tumor growth [8, 32], angiogenesis and disease progression [5, 33]. Lignans from linseed demonstrate the ability to interfere with the phenotype of the malignant tumor, which affects its cellular characteristics. These compounds affect the connections between the molecular signalling networks, which means that they can modulate many signalling cascades at different stages of oncological disease. As a result of these properties, linseed lignans participate in inhibiting the progress of the disease in the patient's body [55].

A pilot scientific study, conducted by Fabian et al. [24], concerned the modulation of biomarkers of breast cancer risk in premenopausal women after administration of plant-diglycoside secoisolariciresinol. In the study, 45 premenopausal women, with regular menstrual cycles, who did not use oral contraceptives for at least 6 months participated. The median age was 49 years, $73 \%$ of women had one or more first-degree relatives with diagnosed breast cancer. $22 \%$ of the participants had previously a biopsy with atypical ductal hypertrophy or lobular carcinoma. Women could be qualified for a random perioperative thin needle aspiration (RPFNA) tissue test if they met the malignant tumor risk criteria. To the risk criteria in the conducted study were considered: 5-year Gail risk $\geq 1.7 \%, 3$ times the average risk determined by Surveillance, Epidemiology, and End Results (SEER) for the relevant age group, biopsy with atypical growth or lobular cancer, or breast cancer diagnosed and treated in the past. Additionally, the qualified patients had to have proper kidney and liver function and no hematological problems. During the 6 weeks before the blood serum samples were taken, participants were required not to use antibiotics or linseed supplements to determine the initial lignan concentration in the patients' blood. The women took $50 \mathrm{mg}$ of SDG daily for 12 months [24].

The concentration of lignans in the patients' blood serum has increased 16 fold in total. The percentage of evaluated women with abnormal cytomorphology was higher at the beginning than at the end of the study $(62 \%$ vs. $42 \%)$. Also the authors of the study noticed a significant change in the category of number of cancer cells with a decrease in their proliferation in $80 \%$ of the participants. Fabian et al. [24] additionally observed a decrease in the percentage of women with cytological types [24].

SDG in physiological solutions provides protection against DNA irradiation by capturing active chlorine types and reducing chlorinated nucleic bases [38]. This property suggests that SDG can be effective in protecting the healthy tissues of an oncological patient during radiotherapy [37]. The molecular pathways associated with the antioxidant properties of flaxseed lignans contribute to the control of many 
cancer characteristics, such as cell death resistance, genome instability and mutation, as well as cell energy deregulation [16].

In addition, the anti-inflammatory properties of flaxseed lignans are well known, which are also effective in cancer. These compounds can modulate the inflammatory process by means of several mechanisms, which include: modulation of immune cell activation through interference with NF-kB pathway signalling [13], reduction in number of proinflammatory cytokines (IL-1 $\beta$, IL-6, TNF $\alpha$, HMGB1 and TGF $\beta 1$ ) and cytokine receptors (TNF $\alpha$ R1 and TGF $\beta$ R1) [44], as well as reduction of cyclooxygenase enzyme activity [19]. Furthermore, the ingredients present in linseed are regulated by miRNA, including miR-150, which is integrated into the intermediary networks with immune response [12]. Linseed lignans play an important role in inhibiting the spread of cancer-induced inflammation in the patient's body [16].

Lignans also have an effect on signal glasses, which are involved in anticancer and antimutagenic processes [1, 42, 46, 47, 57, 61]. Ingredients present in flax seeds are able to positively modulate lipid and glucose homeostasis in the human body. High cholesterol, lipid and glucose levels in the patient's blood serum increase the risk of malignant cancer $[14,20,30,35,48,52,58]$. Changed cholesterol metabolism and its accumulation in the mitochondria of cancer cells can promote continuous cell growth, increase their survival and progression $[4,16,31$, $45,49]$. Lignans have a significant role in cellular energy pathways and lipid homeostasis, which includes the ability to reduce the expression and activity of carnitine palmitoyltransfer 1 (CPT 1), as well as modulation of protein kinase activated by 5'adenosine monophosphate (pAMPK), proliferatoractivated peroxisome $\alpha$ receptor (PPAR $\alpha$ ), fatty acid synthase (FASN), expression and activity of sterol binding protein (SREBP1c). Additionally, lignans have an importance in the expression and activity of adipogenesis-related genes present in leptin, adiponectin, glucose 4 transporter (GLUT-4) and $\gamma$ receptor, activated by peroxisome proliferator (PPAR $\gamma)[17,21,26,40,60]$.

Lignans contained in linseed also have the ability to chemically reduce the factors contributing to breast and colon cancer. Flaxseed compounds are considered as phytoestrogens capable of modulating estrogen receptors and other hormonal functions. The authors of the conducted research suggest that linseed lignans, formed as a result of their metabolism by intestinal bacteria (END and ENL), are able to inhibit hormonedependent proliferation of cancer cells, tumor growth and development of breast, uterus and prostate cancer. This is associated with their similar to estrogen form, which results in the combination of lignans with the same receptors on the surface of cancer cells as estrogen $[9,16,18,34]$.

The authors of scientific studies conducted so far suggest that dietary supplementation with linseed can inhibit the proliferation of cancer and prevent the cancer process initiation [3].

The main drugs used to treat prostate cancer are docetaxel and doxorubicin. Both drugs inhibited PC3 tumour cell growth with an $\mathrm{IC}_{50}$ value of 0.9 $\mathrm{nM}$ and $0.2 \mu \mathrm{M}$, respectively. $D i$ [18] in his $\mathrm{PhD}$ thesis observed that at a concentration of $50 \mu \mathrm{M}$ of secoisolariciresino, the $\mathrm{IC}_{50}$ value of docetaxel was reduced by $60 \%$ (to $0.37 \mathrm{nM}$ ). Whereas enterolactone reduced the $\mathrm{IC}_{50}$ value of docetaxel to $0.09 \mathrm{nM}$ with a $90 \%$ growth inhibition at a concentration of $50 \mu \mathrm{M}$. The study reported no significant difference between $50 \mu \mathrm{M}$ of secoisolariciresinol or enterolactone with doxorubicin in PC3 cancer cells. Di [18] considers that the results obtained in his scientific study indicate that the linseed metabolites SECO and ENL, significantly increase the sensitivity of prostate cancer cells to many of the chemotherapeutic agents used in its treatment. However, he highlights that ENL lignan causes greater cytotoxicity to prostate cancer cells, either when used alone or in combination with chemotherapy, compared to the minor therapeutic effect of SECO observed in the study [18].

In the meta-analysis by Perez-Cornago et al. [43], a total of 241 cases and 503 controls from two Japanese prospective studies and 2828 cases and 5593 controls from five European prospective studies were analysed. The studies considered for the metaanalysis included data on serum phytoestrogen concentrations in participants prior to diagnosis of malignant prostate cancer. Five studies, eligible for meta-analysis, were concerned with enterolactone levels (2828 cases and 5593 controls) and 2 studies analysed with serum enterodiol levels (1002 cases and 1197 controls) in participants. Perez-Cornago et al. on the basis of their analysis of scientific studies did not note existing strong evidence supporting the importance of lignan concentrations in prediagnosis with prostate malignancy risk [43]. Additionally, Eriksen et al. in a cohort study reported no association between prediagnostic enterolactone levels and mortality among men diagnosed with prostate malignancy [23].

\section{DIETARY LINSEED SUPPLEMENTATION - IS IT ABSOLUTELY SAFE?}

In scientific studies with oncological patients, the benefits of linseed consumption are unclear. There is a confusion as to the most appropriate lignan intake, 
which is associated with the problem of determining the lignan serum levels in patients' blood [16]. It should be highlighted that an excessive dietary supplementation of omega-3 acids may increase the risk of hemorrhagic complications [29]. Some scientific reports have emerged about the possibility of reducing the anti-cancer drug tamoxyphene, whose action was to inhibit the estrogen activity on cancer cells in the patients' organisms, during the pharmacological therapy of breast cancer. Their authors carried out studies with laboratory animals, in which they noted that flax seeds can reduce the absorption of drugs. Therefore, it is necessary to consume linseed at least 1 hour before or 2 hours after taking the pharmaceuticals [2].

Tamoxifen is cancer, particularly in estrogen receptor positive (ER+) women. According to Calado et al. [36] flaxseed does not interact with drugs used in the treatment of malignant breast cancer. Additionally, flaxseed supplementation may provide an additional protective effect during the course of treatment [36].

In a scientific study with laboratory animals, the authors observed that supplementation with flaxseed, linseed oil or SDG, combined with tamoxifen treatment reduced tumour size to a greater extent than chemotherapy alone [25].

Similar results were also obtained by researchers at the University of Toronto. In their study, mice were injected with MCF-7 breast tumours. The animals were divided into 3 groups, one taking 20-25 g of ground flaxseed, another tamoxifen $(5 \mathrm{mg})$ and the third a combination of both methods. The authors of the study observed that combined treatment with the chemotherapeutic agent and flaxseed inhibited malignant tumour growth $53 \%$ more effectively than treatment with tamoxifen alone [11].

However, the efficacy of dietary flaxseed supplementation in combination with conventional therapies is not clear. A pilot scientific study involving 24 postmenopausal women diagnosed with ER+ breast cancer analysed the efficacy of flaxseed and the aromatase inhibitor anastrozole (one of the drugs used to treat breast cancer) and possible interactions between them. The women were divided into 4 groups. The first took $25 \mathrm{~g}$ of ground flax seeds and 1 placebo tablet per day, the second took $1 \mathrm{mg}$ of anastrozole per day, the third took $25 \mathrm{~g}$ of ground flax seeds and $1 \mathrm{mg}$ of anastrozole per day, while group 4 took only 1 placebo pill per day. The authors of the study reported no effect of flaxseed on aromatase inhibitor activity in selected breast cancer characteristics and serum steroid hormone levels of the participants [36].

Nevertheless, a scientific study by $D i$ et al. [17] examined whether linseed lignans increased the cytotoxicity of chemotherapeutic agents on selected groups of breast cancer cells. The authors observed that the combination of linseed lignans (secoisolaciresinol and enterolactone), with commonly used chemotherapeutic drugs (docetaxel, doxorubicin and carboplatin), exhibiting different mechanisms of therapeutic action, significantly increased the ability of chemotherapy to induce cytotoxicity in SKBR3 and MDA-MB-231 cancer cells. $D i$ et al. claim that the in vitro results they received suggest a future direction for improving the efficacy of chemotherapy in the treatment of malignant breast cancer by introducing adjuvant therapy with flaxseed lignans [17].

The American Institute for Cancer Research recommends consultation with a doctor or health care professional regarding the possibility of consuming flax seeds while taking supplements or anticoagulants. The AICR, due to contradictory clinical evidences, also concludes that further scientific research is needed to confirm whether there is an benefit from flaxseed consumption as part of the prevention or treatment of specific types of diagnosed prostate malignant tumors [2].

Based on the available information, European Food Safety Authority (EFSA) concludes that the effects of flaxseeds and lignans on hormone secretion, as observed in in vitro studies and in laboratory animals on tumour cell growth and reproduction, may be beneficial or detrimental depending on the dose, duration and time of exposure to lignans. EFSA considers that not only the potential beneficial health effects, but also the possible adverse effects that consumption of lignans may cause at a certain stage of human development should be taken into account. EFSA also concludes that lignans present in flax seeds do not exhibit genotoxicity, but highlights that there are no scientific studies available on the carcinogenicity of lignans. According to the scientific studies reviewed, EFSA estimated the intake of lignans from food supplements to be in the range of $35-312 \mathrm{mg} / \mathrm{day}$. This equates to an intake of 0.58 to $5.2 \mathrm{mg} / \mathrm{kg} / \mathrm{day}$ by a person of $60 \mathrm{~kg}$ body weight [28].

In contrast, the safety range for the intake of lignans contained in food is from 31 to $275 \mathrm{mg} /$ day. EFSA also emphasises that the safety of use of dietary supplements whose main ingredient is lignans in pregnant or lactating women has not been established. It also recommends caution in the use of these supplements in women with a physiological, hormone-sensitive condition (e.g. endometriosis, polycystic ovarian syndrome, uterine fibroids, breast, uterine or ovarian cancer). EFSA also underlines that women diagnosed with hormone-dependent breast cancer should avoid lignans [28]. 
In addition, long-term consumption of flaxseed has been shown to increase the concentration of thiocyanates in plasma and excreted in urine. Regular consumption of flaxseeds induces an accumulation of thiocyanates comparable to their concentration in the blood serum of compulsive smokers. However, consumption of up to $100 \mathrm{~g}$ of flaxseed per day does not cause any change in the concentration of cyanides in human blood serum. However, EFSA emphasises that the available scientific data on the cyanide content of flaxseeds and its potential risks for human health are insufficient and require additional scientific evidence [28].

EFSA has also published health claims for linseed oil and linseed. The health relationship and suggested wording of the claim for the individual food or its ingredients are shown in Table 1 [22].

\section{COMMERCIALLY AVAILABLE DIETARY SUPPLEMENTS WITH SDG}

The most available dietary supplements on the market, containing linseed lignans, are designed to regulate the concentration of sex hormones. In women's hormone management, flaxseed lignans are supposed to contribute to alleviate the effects of the menopause and demonstrate antioxidant effects. Whereas manufacturers of dietary supplements for men, declare the protective effect of the prostate, increase in libido, free testosterone and also increase in strength and muscle mass. In the pharmaceuticals' intended use descriptions, manufacturers also declare beneficial effects on patients' cardiovascular system and removal of free radicals from their organisms.

In turn supplements, of which flax seeds are a component, are intended to improve the digestive tract function, by complementing the diet with dietary fiber.

In case of using products made of linseed oil, it is intended to complement the diet with essential unsaturated fatty acids (mainly $\alpha$-linolenic acid), support the immune and cardiovascular system as well as have a positive effect on the patient's lipid profile. The dietary supplements selected and analysed in this study are presented in Table 2.

It should also be highlighted that one of the manufacturers, which declares on its website that the health claims it has made regarding the effectiveness of the food supplement have not been evaluated by the Food and Drug Administration (FDA). FDA also emphasizes that this product is not intended to diagnose, treat or prevent any disease. The website also contains information about differences in lignan content in the dietary supplement, by 3-5\% [41].

\section{CONCLUSIONS}

From the review of the world's scientific literature it is not possible to unequivocally confirm the effectiveness and validity of supplementation with flax seeds or their lignans alone, as monotherapy or in support of conventional therapies - chemotherapy or radiotherapy.

There are scientific evidence of their efficacy in oncological diseases, but the therapeutic effects of linseed in oncology are closely related to the type of malignant tumour and the specific cancer cells. Further clinical studies are needed to clearly establish the validity of dietary supplementation with SDG from flaxseed in cancer.

Examined pharmaceutical products available in pharmacies and e-stores, containing in their composition linseed lignans, linseed oil or linseed, are characterized by different therapeutic effects declared by the manufacturers. Most of the available dietary supplements, containing SDGs in their composition, were designed to alleviate menopausal symptoms, support the immune and the endocrine system. Pharmaceutical manufacturers of food supplements containing linseed lignans declared that the use of the supplement by men would have a beneficial effect on prostate function, libido and serum testosterone levels.

None of the pharmaceutical supplements analysed and found were directly intended for people with oncological disease. The only information that could suggest a benefit of using a dietary supplement by patients with malignant tumours is the claimed protection of cells against oxidative stress that occurs during the disease. 


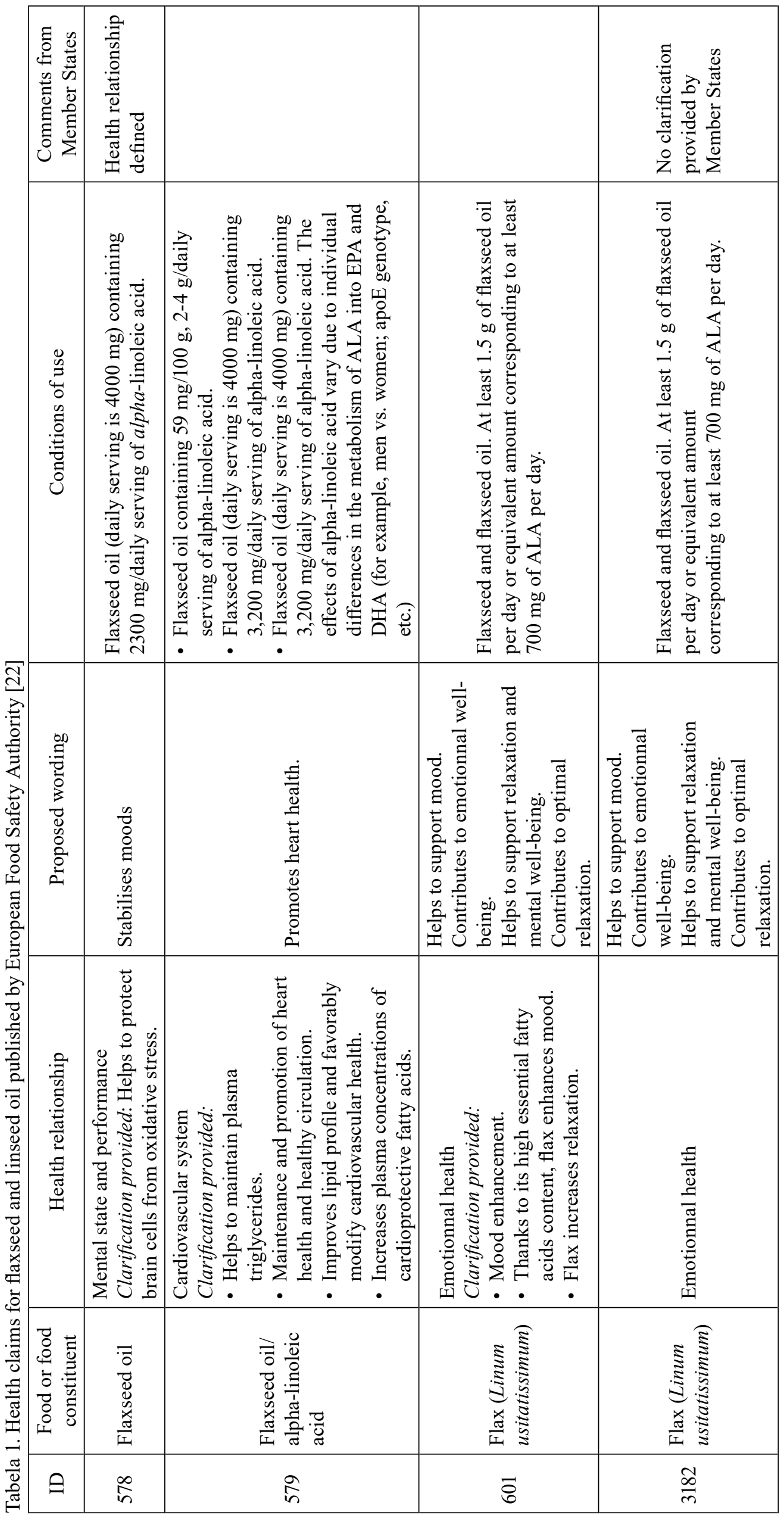




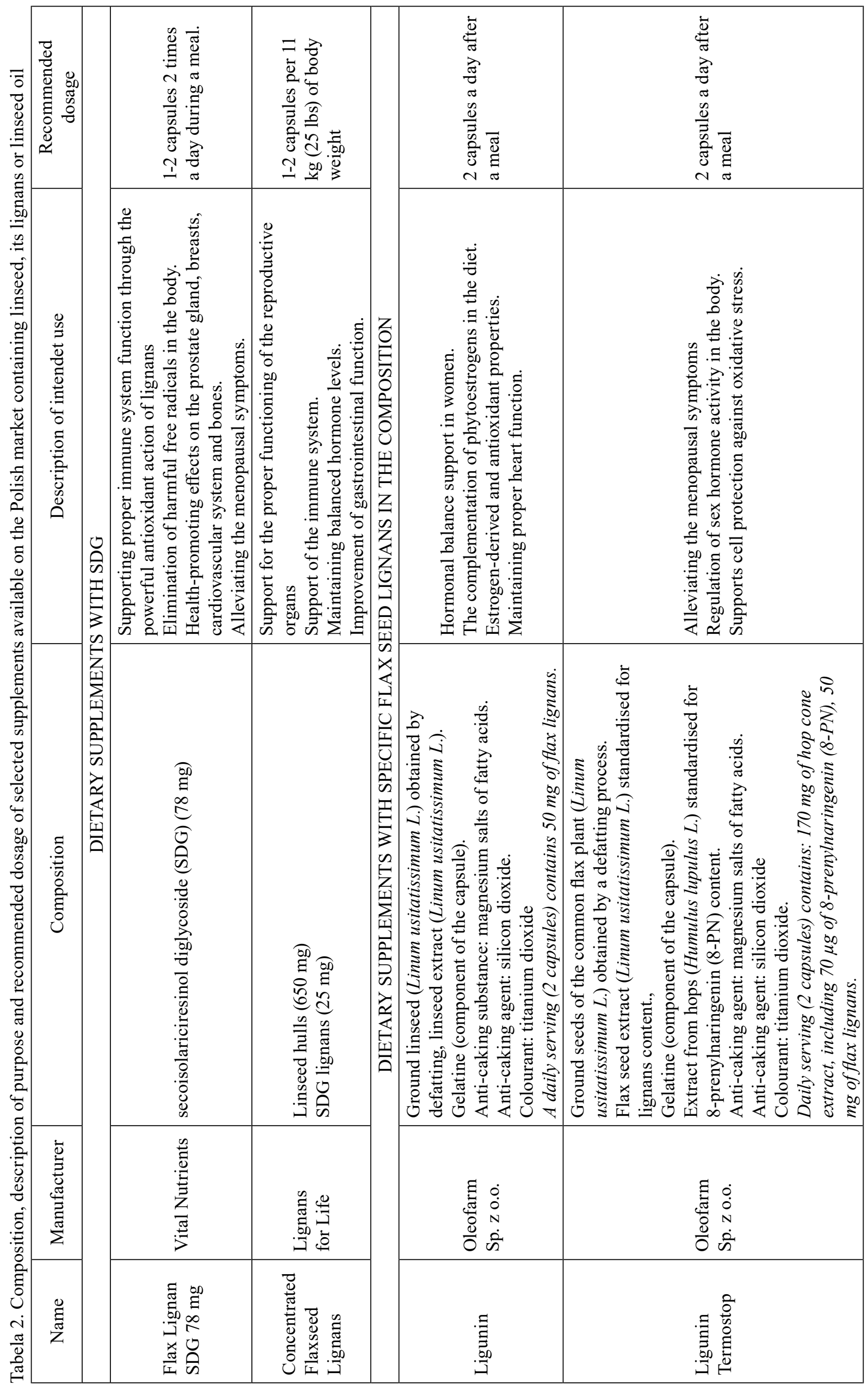




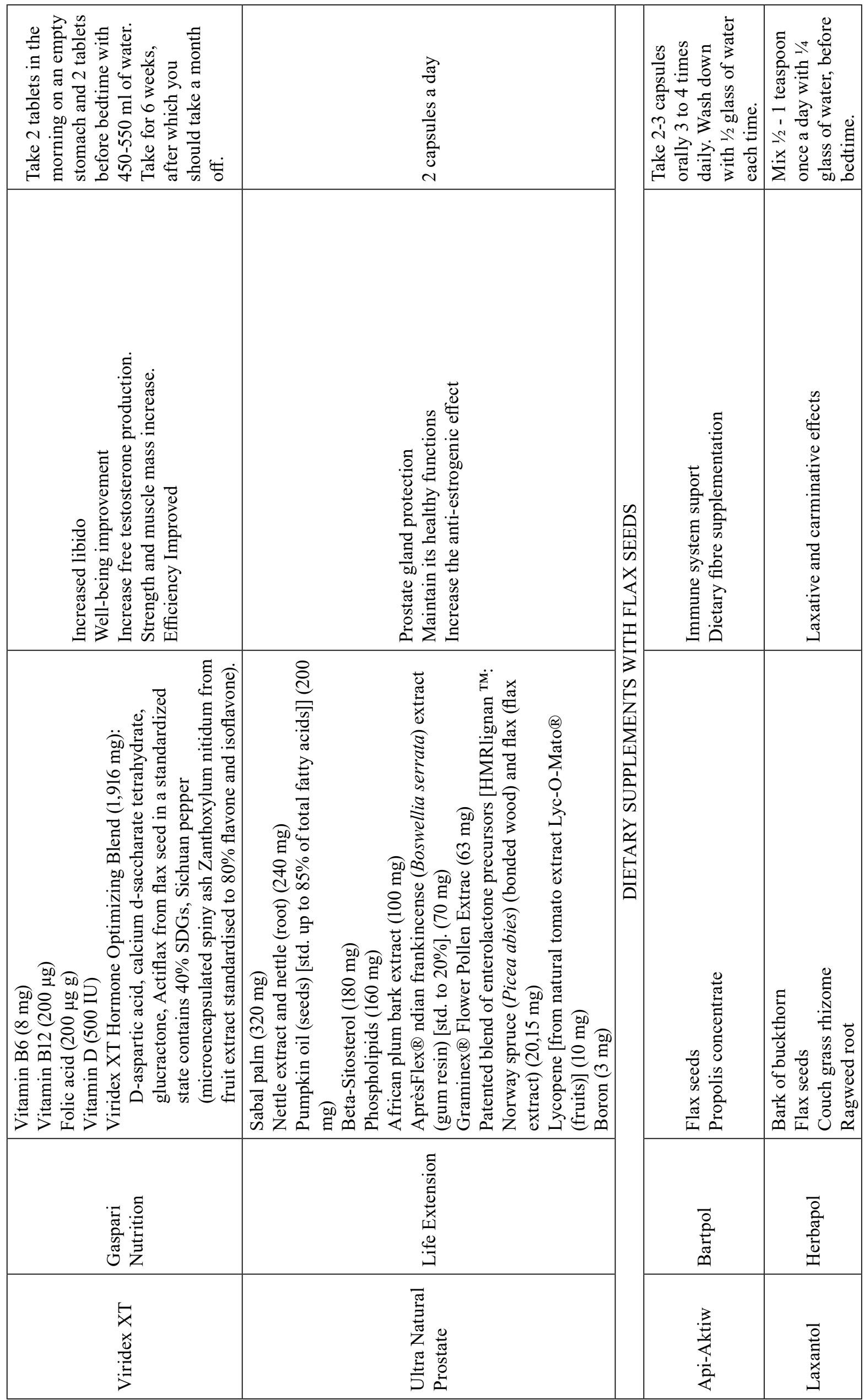




\begin{tabular}{|c|c|c|c|c|}
\hline 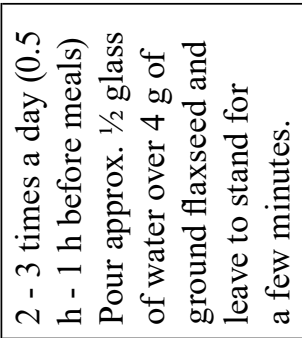 & & 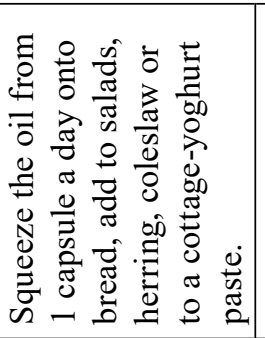 & 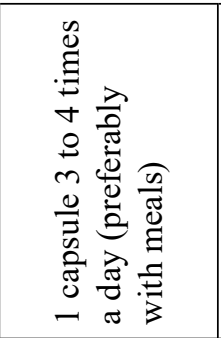 & 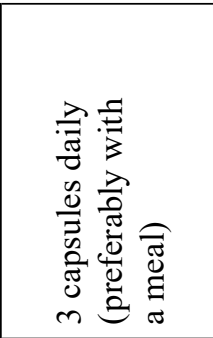 \\
\hline 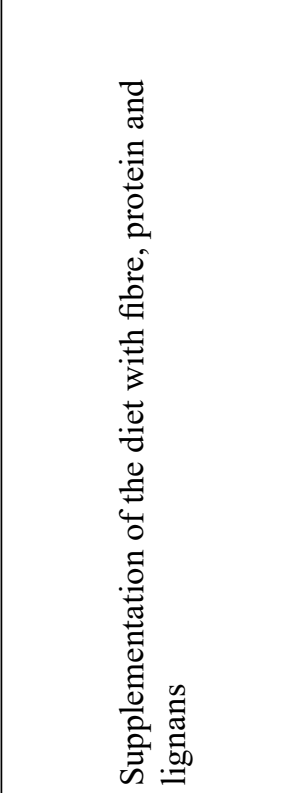 & 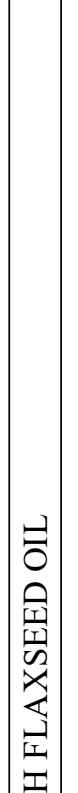 & 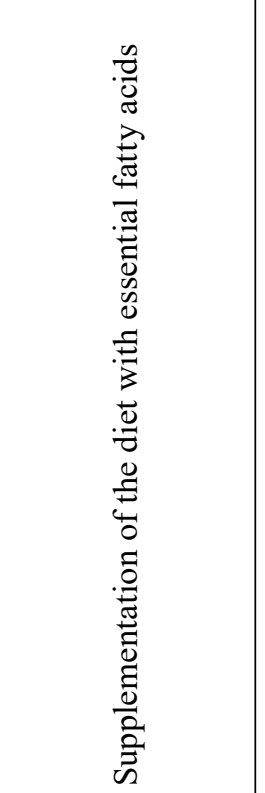 & 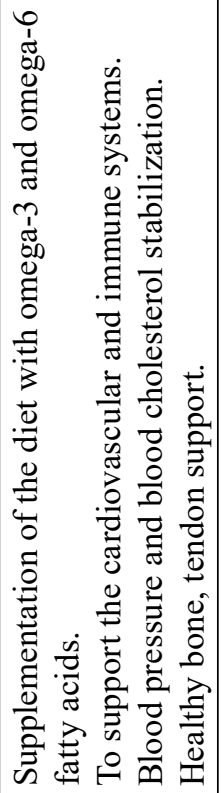 & 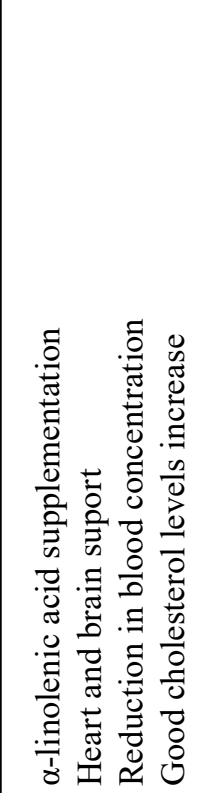 \\
\hline 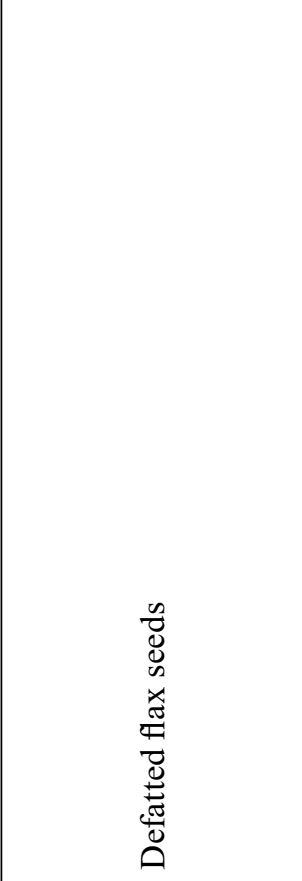 & 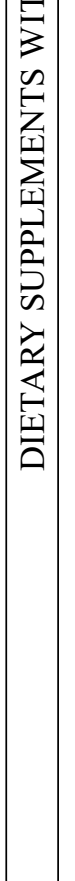 & 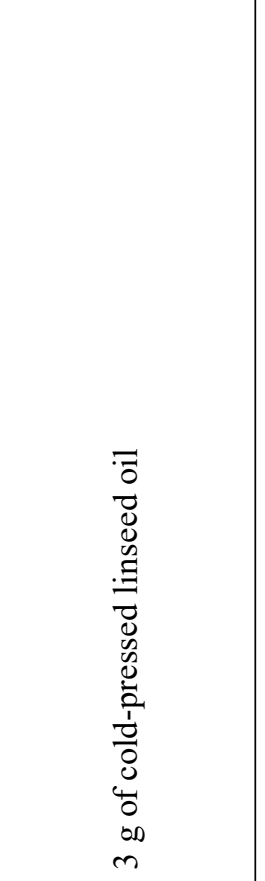 & 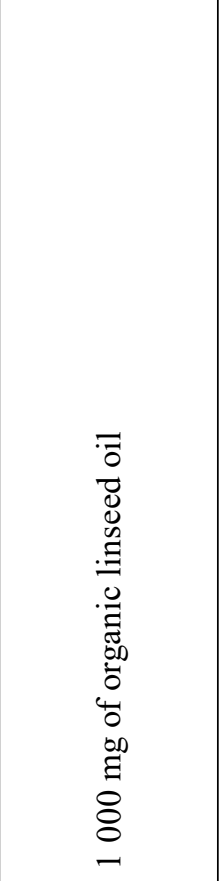 & 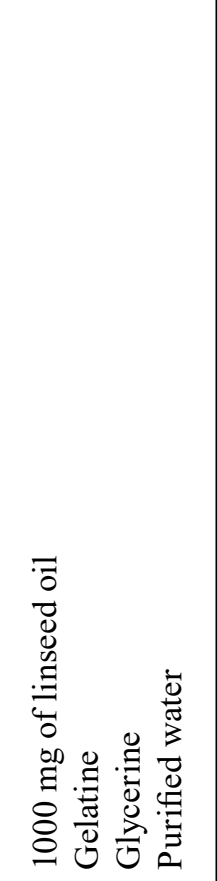 \\
\hline$\sum_{\dot{\Delta}}^{\infty}$ & & 応 & 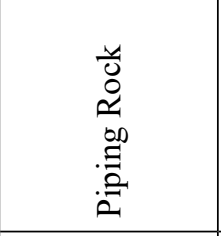 & 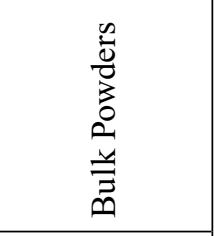 \\
\hline 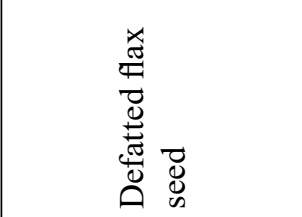 & & 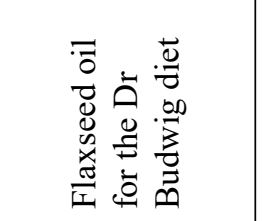 & 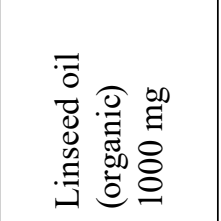 & 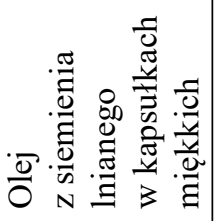 \\
\hline
\end{tabular}




\section{REFERENCES}

1. Almario R.U., Karakas S.E.: Lignan content of the flaxseed influences its biological effects in healthy men and women. J Am Coll Nutr. 2013;32(3):194-199. doi:10 $.1080 / 07315724.2013 .791147$

2. American Institute for Cancer Research. Available https://www.aicr.org/patients-survivors/healthy-orharmful/flaxseed.html (Accessed 11.10.2019)

3. Ansenberger K., Richards C., Zhuge Y., Barua A., Bahr J.M., Luborsky J.L., Hales D.B.: Decreased severity of ovarian cancer and increased survival in hens fed a flaxseed-enriched diet for 1 year. Gynecol Oncol. 2010;117(2):341-347. doi:10.1016/j.ygyno.2010.01.021

4. Beloribi-Djefaflia S., Vasseur S., Guillaumond F.: Lipid metabolic reprogramming in cancer cells. Oncogenesis. 2016;5(1):e189. Published 2016 Jan 25. doi:10.1038/ oncsis.2015.49

5. Bergman Jungeström M., Thompson L.U., Dabrosin $C .:$ Flaxseed and its lignans inhibit estradiol-induced growth, angiogenesis, and secretion of vascular endothelial growth factor in human breast cancer xenografts in vivo. Clin Cancer Res. 2007;13(3):10611067. doi:10.1158/1078-0432.CCR-06-1651

6. Blendon R.J., DesRoches C.M., Benson J.M., Brodie M., Altman D.E.: Americans' views on the use and regulation of dietary supplements. Arch Intern Med. 2001;161(6):805-810. doi:10.1001/archinte.161.6.805

7. Boker L.K., van der Schouw Y.T., De Kleijn M.J., Jacques P.F., Grobbee D.E., Peeters P.H.: Intake of dietary phytoestrogens by Dutch women. J Nutr. 2002;132(6):1319-1328. doi:10.1093/jn/132.6.1319

8. Bylund, A., Zhang, J. X., Bergh, A., Damber, J. E., Widmark, A., Johansson, A., Adlercreutz, H., Aman, P., Shepherd, M. J., \& Hallmans, G.: Rye bran and soy protein delay growth and increase apoptosis of human $\mathrm{LNCaP}$ prostate adenocarcinoma in nude mice. The Prostate. 2000;42(4):304-314. doi:10.1002/(sici)10970045(20000301)42:4<304::aid-pros8 $>3.0 . c 0 ; 2-z$

9. Calado A., Neves P.M., Santos T., Ravasco P.: The effect of flaxseed in breast cancer: a literature review. Front Nutr. 2018;5:4. doi:10.3389/fnut.2018.00004

10. Carreau C, Flouriot G, Bennetau-Pelissero C, Potier $M$ : : Enterodiol and enterolactone, two major dietderived polyphenol metabolites have different impact on ERalpha transcriptional activation in human breast cancer cells. J Steroid Biochem Mol Biol. 2008;110(12):176-185. doi:10.1016/j.jsbmb.2008.03.032

11. Chen J., Hui E., Ip T., Thompson L. U.: Dietary flaxseed enhances the inhibitory effect of tamoxifen on the growth of estrogen-dependent human breast cancer (mcf-7) in nude mice. Clin Cancer Res. 2004;10(22):7703-11. doi: 10.1158/1078-0432.CCR-04-1130.

12.Christofidou-Solomidou M., Pietrofesa R., Arguiri E., McAlexander M.A., Witwer K.W.: Dietary flaxseed modulates the miRNA profile in irradiated and non-irradiated murine lungs: a novel mechanism of tissue radioprotection by flaxseed. Cancer Biol Ther. 2014;15(7):930-937. doi:10.4161/cbt.28905
13. Corsini E., Dell'Agli M., Facchi A., De Fabiani E., Lucchi L., Boraso M.S., Marinovich M., Galli C.L.: Enterodiol and enterolactone modulate the immune response by acting on nuclear factor-kappaB (NF-kappaB) signaling. J Agric Food Chem. 2010;58(11):6678-6684. doi:10.1021/jf100471n

14. Cui G., Zhang T., Ren F., Feng W. M., Yao Y., Cui J., Zhu G. L., Shi Q. L.: High blood glucose levels correlate with tumor malignancy in colorectal cancer patients. Med Sci Monit. 2015;21:3825-3833. doi:10.12659/msm.894783

15. de Kleijn, M. J., van der Schouw, Y. T., Wilson, P. W., Adlercreutz, H., Mazur, W., Grobbee, D. E., \& Jacques, $P$. F.: Intake of dietary phytoestrogens is low in postmenopausal women in the United States: the Framingham study(1-4). J Nutr. 2001;131(6):1826-1832. doi:10.1093/jn/131.6.1826

16.De Silva S.F., Alcorn J.: Flaxseed Lignans as Important Dietary Polyphenols for Cancer Prevention and Treatment: Chemistry, Pharmacokinetics, and Molecular Targets. Pharmaceuticals (Basel). 2019;12(2):68. doi:10.3390/ph12020068

17. Di Y., De Silva F., Krol E.S., Alcorn J.: Flaxseed lignans enhance the cytotoxicity of chemotherapeutic agents against breast cancer cell lines MDA-MB-231 and SKBR3. Nutr Cancer. 2018;70(2):306-315. doi:10.1080/ 01635581.2018 .1421677

18. Di Y.: Flaxseed lignan supplementation as possible adjuvant therapy for prostate and breast cancer, Ph.D. Thesis, University of Saskatchewan, Saskatoon, SK, Canada, 2017

19. Dikshit A., Gomes Filho M.A., Eilati E., McGee S., Small C., Gao C., Klug T., Hales D.B.: Flaxseed reduces the pro-carcinogenic micro-environment in the ovaries of normal hens by altering the PG and oestrogen pathways in a dose-dependent manner. Br J Nutr. 2015;113(9):13841395. doi:10.1017/S000711451500029X

20.Ding E.L., Hu F.B.: Cancer and cholesterol: understanding the V-shaped association in patients with diabetes. CMAJ. 2008;179(5):403-404. doi:10.1503/ cmaj.081069

21.Drygalski K., Berk K., Charytoniuk T., Ilowska N., Lukaszuk B., Chabowski A., Konstantynowicz-Nowicka $K$ : Does the enterolactone (ENL) affect fatty acid transporters and lipid metabolism in liver?. Nutr Metab (Lond). 2017;14:69. doi:10.1186/s12986-017-0223-1

22.EFSA Panel on Dietetic Products, Nutrition and Allergies (NDA): Scientific Opinion on the substantiation of health claims related to alpha-linolenic acid (ALA) and brain and neurological development (ID 491), "molecule precursors regulating cell functions" (ID 492, 4671), maintenance of normal cardiac function (ID 509, 579), "nutrient tasks and interactions" (ID 576), maintenance of normal blood pressure (ID 575), and enhancement of mood (ID 578, 601, 3182) pursuant to Article 13(1) of Regulation (EC) No 1924/2006. EFSA Journal 2011;9(4):2050. [24 pp.]. doi:10.2903/j. efsa.2011.2050

23.Eriksen A. K., Kyrø C., Nørskov N., Bolvig A. K., Christensen J., Tjønneland A., Overvad K., Landberg $R$. ., Olsen A.: Prediagnostic enterolactone concentrations and mortality among Danish men diagnosed with 
prostate cancer. Eur J Clin Nutr. 2017;71(10):1235-1240. doi: 10.1038/ejcn.2017.42.

24.Fabian, C. J., Kimler, B. F., Zalles, C. M., Klemp, J. R., Petroff, B. K., Khan, Q. J., Sharma, P., Setchell, K. D., Zhao, X., Phillips, T. A., Metheny, T., Hughes, J. R., Yeh, H. W., \& Johnson, K. A.: Reduction in Ki-67 in benign breast tissue of high-risk women with the lignan secoisolariciresinol diglycoside. Cancer Prev Res (Phila). 2010;3(10):1342-1350. doi:10.1158/1940-6207. CAPR-10-0022

25.Flower G., Fritz H., Balneaves L. G., Verma S., Skidmore B., Fernandes R., Kennedy D., Cooley K., Wong R., Sagar S., Fergusson D., Seely D.: Flax and breast cancer: a systematic review. Integr Cancer Ther. 2014;13(3):181-92. doi: 10.1177/1534735413502076

26.Fukumitsu S., Aida K., Ueno N., Ozawa S., Takahashi $Y$., Kobori M.: Flaxseed lignan attenuates high-fat dietinduced fat accumulation and induces adiponectin expression in mice. Br J Nutr. 2008;100(3):669-676. doi:10.1017/S0007114508911570

27. Gröber U., Holzhauer P., Kisters K., Holick M.F., Adamietz I.A.: Micronutrients in Oncological Intervention. Nutrients. 2016;8(3):163. doi:10.3390/ nu8030163

28. Grupa Robocza EFSA ds. Wspótpracy Naukowej (ESCO) $w$ Zakresie Substancji i preparatów Botanicznych: Opinia w sprawie wytycznych EFSA dotyczących oceny bezpieczeństwa substancji i preparatów botanicznych używanych jako suplementy diety sporządzona w oparciu o realne studia przypadków na wniosek EFSA [Opinion on EFSA guidance on the safety assessment of botanical substances and preparations used as food supplements based on real life case studies on request from EFSA.]. Dziennik EFSA 2009; (9):280. [104 str.] doi:10.2903/j.efsa.2009.280 (in Polish).

29. Kiedrowski M., Gajewska D.: Co powinien wiedzieć lekarz rodzinny o popularnych ,dietach odchudzających" i samym odchudzaniu? [What should the general practitioner know about popular "slimming diets" and weight loss?]. Med Rodz, 2013;3:95-98 (in Polish).

30. Kitahara C.M., Berrington de González A., Freedman N.D., Huxley R., Mok Y., Jee S.H., Samet J.M.: Total cholesterol and cancer risk in a large prospective study in Korea. J Clin Oncol. 2011;29(12):1592-1598. doi:10.1200/JCO.2010.31.5200

31. Kuzu O.F., Noory M.A., Robertson G.P.: The Role of Cholesterol in Cancer. Cancer Res. 2016;76(8):20632070. doi:10.1158/0008-5472.CAN-15-2613

32.Landström, M., Zhang, J. X., Hallmans, G., Aman, P., Bergh, A., Damber, J. E., Mazur, W., Wähäla, K., \& Adlercreutz, $H$ :: Inhibitory effects of soy and rye diets on the development of Dunning R3327 prostate adenocarcinoma in rats. Prostate. 1998;36(3):151-161. doi:10.1002/(sici)1097-0045(19980801)36:3<151::aid$\operatorname{pros} 2>3.0 . \operatorname{co} ; 2-\mathrm{k}$

33. Lin X., Gingrich J.R., Bao W., Li J., Haroon Z.A., DemarkWahnefried $W$ : Effect of flaxseed supplementation on prostatic carcinoma in transgenic mice. Urology. 2002;60(5):919-924. doi:10.1016/s0090-4295(02)01863-0
34.Liu H., Liu J., Wang S., Zeng Z., Li T., Liu Y., Mastriani E., Li Q.H., Bao H.X., Zhou Y.J., Wang X., Hu S., Gao S., Qi Y., Shen Z., Wang H., Yu M., Gao T., Johnston R.N., Liu S.L.: Enterolactone has stronger effects than enterodiol on ovarian cancer. J Ovarian Res. 2017;10(1):49. doi:10.1186/s13048-017-0346-z

35. May-Wilson S., Sud A., J Law P., Palin K., Tuupanen S., Gylfe A., Hänninen U.A., Cajuso T.2, Tanskanen T., Kondelin J., Kaasinen E., Sarin A-P., Eriksson J.G., Rissanen H., Knekt P., Pukkala E., Jousilahti P., Salomaa V., Ripatti S., Palotie A., Renkonen-Sinisalo L., Lepistö A., Böhm J., Mecklin J-P., Al-Tassan N.A., Palles C., Farrington S.M., Timofeeva M.N., Meyer B.F., Wakil S.M., Campbell H., Smith Ch.G., Idziaszczyk S., Maughan T.S., Fisher D., Kerr R., Kerr D., Passarelli M.N., Figueiredo J.C., Buchanan D.D., Win A.K., Hopper J.L., Jenkins M.A., Lindor N.M., Newcomb P.A., Gallinger S., Conti D., Schumacher F., Casey G., Aaltonen L.A., Cheadle J.P., Tomlinson I.P., Dunlop M.G., Houlston R.S.: Pro-inflammatory fatty acid profile and colorectal cancer risk: A Mendelian randomisation analysis. Eur J Cancer. 2017;84:228-238. doi:10.1016/j.ejca.2017.07.034

36. McCann S. E., Edge S. B., Hicks D. G., Thompson L. U., Morrison C. D., Fetterly G., Andrews C., Clark K., Wilton J., Kulkarni S.: A pilot study comparing the effect of flaxseed, aromatase inhibitor, and the combination on breast tumor biomarkers. Nutr Cancer. 2014;66(4):56675. doi: 10.1080/01635581.2014.894097.

37. Mishra O.P., Pietrofesa R., Christofidou-Solomidou $M$ : Novel synthetic (S,S) and (R,R)-secoisolariciresinol diglucosides (SDGs) protect naked plasmid and genomic DNA From gamma radiation damage. Radiat Res. 2014;182(1):102-110. doi:10.1667/RR13635.1

38. Mishra O.P., Popov A.V., Pietrofesa R.A., ChristofidouSolomidou M:: Gamma-irradiation produces active chlorine species (ACS) in physiological solutions: Secoisolariciresinol diglucoside (SDG) scavenges ACS - A novel mechanism of DNA radioprotection. Biochimica et biophysica acta 2016;1860(9):1884-1897 doi:/10.1016/j.bbagen.2016.05.037

39. Mueller S.O., Simon S., Chae K., Metzler M., Korach K.S.: Phytoestrogens and their human metabolites show distinct agonistic and antagonistic properties on estrogen receptor $\alpha(\mathrm{ER} \alpha)$ and $\mathrm{ER} \beta$ in human cells, Toxicological Sciences. 2004;80(1):14-25. https://oi. org/10.1093/toxsci/kfh147

40.Mukker, J.: Pharmacokinetic and pharmacodynamic studies on flaxseed lignans. Ph.D. Thesis, University of Saskatchewan, Saskatoon, SK, Canada, 2013

41. Online store amazon.com. Available https://www. amazon.com/Lignans-For-Life-lignans-bottle/dp/ B0047LZ0SA (Accessed 07.02.2020)

42.Pan A., Sun J., Chen Y., Ye, X., Li H., Yu Z., Wang Y., Gu $W$., Zhang X., Chen X., Demark-Wahnefried W., Liu Y., Lin $X$.: Effects of a flaxseed-derived lignan supplement in type 2 diabetic patients: A randomized, doubleblind, cross-over trial. PLoS ONE 2007;2(11):e1148. doi:10.1371/journal.pone.0001148

43. Perez-Cornago A., Appleby P. N., Boeing H., Gil L., Kyrø C., Ricceri F., Murphy N., Trichopoulou A., Tsilidis K. 
K., Khaw K. T., Luben R. N., Gislefoss R. E., Langseth H., Drake I., Sonestedt E., Wallström P., Stattin P., Johansson A., Landberg R., Nilsson L. M., Ozasa K., Tamakoshi A., Mikami K., Kubo T., Sawada N., Tsugane S., Key T. J., Allen N. E., Travis R. C.: Circulating isoflavone and lignan concentrations and prostate cancer risk: a meta-analysis of individual participant data from seven prospective studies including 2,828 cases and 5,593 controls. Int J Cancer. 2018;143(11):2677-2686. doi: $10.1002 / \mathrm{ijc} .31640$.

44.Pietrofesa R. A., Velalopoulou A., Arguiri E., Menges C. W., Testa J. R., Hwang W. T., Albelda S. M., Christofidou-Solomidou M.: Flaxseed lignans enriched in secoisolariciresinol diglucoside prevent acute asbestos-induced peritoneal inflammation in mice. Carcinogenesis. 2016;37(2):177-187. doi:10.1093/carcin/ bgv174

45. Porporato P.E., Filigheddu N., Pedro J.M.B., Kroemer, G., Galluzzi, L.: Mitochondrial metabolism and cancer. Cell Res. 2018;28:265-280. doi:10.1038/cr.2017.155

46. Prasad K., Dhar A.: Flaxseed and Diabetes. Curr Pharm Des. 2016;22(2):141-144. doi:10.2174/1381612822666151 112151230

47. Prasad K: Flax lignan complex slows down the progression of atherosclerosis in hyperlipidemic rabbits. J Cardiovasc Pharmacol Ther. 2009;14(1):3848. doi:10.1177/1074248408330541

48.Radišauskas R., Kuzmickienè I., Milinavičiené E., Everatt R.: Hypertension, serum lipids and cancer risk: A review of epidemiological evidence. Medicina (Kaunas). 2016;52(2):89-98. doi:10.1016/j.medici.2016.03.002

49. Ribas V., García-Ruiz C., Fernández-Checa J.C.: Mitochondria, cholesterol and cancer cell metabolism. Clin Transl Med. 2016;5(1):22. doi:10.1186/s40169-0160106-5

50.Rock C.L.: Multivitamin-multimineral supplements: who uses them?. Am J Clin Nutr. 2007;85(1):277S-279S. doi:10.1093/ajen/85.1.277S

51.Rybus K., Kozłowska-Wojciechowska M.: The use of dietary supplements and over-the-counter (OTC) medicines by the elderly - survey results. Czynniki Ryzyka 2010;1:32-37 (in Polish).

52.Ryu T.Y., Park J., Scherer P.E.: Hyperglycemia as a risk factor for cancer progression. Diabetes Metab J. 2014;38(5):330-336. doi:10.4093/dmj.2014.38.5.330

53. Sadovsky R., Collins N., Tighe A.P., Brunton S.A., Safeer $R .:$ Patient use of dietary supplements: a clinician's perspective. Curr Med Res Opin. 2008;24(4):1209-1216. doi:10.1185/030079908x280743

54.Silska G.: Polska kolekcja lnu - źródłem nasion o terapeutycznym działaniu [The Polish Flax Collectiona source of seeds with therapeutic activity]. Zagadnienia Doradztwa Rolniczego. 2016;4(86):73-81 (in Polish).

55. Teponno, R. B., Kusari, S., \& Spiteller, M.: Recent advances in research on lignans and neolignans. Natural product reports. 2016;33(9):1044-1092. doi:10.1039/ c6np00021e

56.Thompson L.U., Boucher B.A., Liu Z., Cotterchio M., Kreiger N.: Phytoestrogen content of foods consumed in Canada, including isoflavones, lignans, and coumestan. Nutr Cancer. 2006;54(2):184-201. doi:10.1207/ s15327914nc5402_5

57. Torkan M., Entezari M.H., Siavash M.: Effect of flaxseed on blood lipid level in hyperlipidemic patients. Rev Recent Clin Trials. 2015;10(1):61-67. doi:10.2174/15748 87110666150121154334

58.Vulcan A., Manjer J., Ohlsson B.: High blood glucose levels are associated with higher risk of colon cancer in men: a cohort study. BMC Cancer. 2017;17(1):842. doi:10.1186/s12885-017-3874-4

59. Wierzejska R.: Suplementy diety - panaceum na współczesne dolegliwości zdrowotne czy triumf reklamy? [Dietary supplements - panacea to contemporary health problems, or the triumph of advertisement?]. Med Rodz 2017; 20(2): 136-142 (in Polish).

60. Yoshii Y., Furukawa T., Oyama N., Hasegawa Y., Kiyono Y., Nishii R., Waki A., Tsuji A.B., Sogawa C., Wakizaka H., Fukumura T., Yoshii H., Fujibayashi Y., Lewis J.S., Saga T.: Fatty acid synthase is a key target in multiple essential tumor functions of prostate cancer: uptake of radiolabeled acetate as a predictor of the targeted therapy outcome. PLoS One. 2013;8(5):e64570. doi:10.1371/journal.pone.0064570

61. Zhang, W.; Wang, X.; Liu, Y.; Tian, H.; Flickinger, B.; Empie, M.W.; Sun, S.Z.: Dietary flaxseed lignan extract lowers plasma cholesterol and glucose concentrations in hypercholesterolaemic subjects. $\mathrm{Br} \mathrm{J}$ Nutr. 2008;99(6):1301-1309. doi:10.1017/S0007114507871649

Received: 05.11.2020

Accepted: 25.01.2021 